\title{
A Sociology of Foreign Aid and the World Society ${ }^{1}$
}

\author{
Liam Swiss \\ Memorial University
}

Appears in Sociology Compass 10(1): 65-73.

\begin{abstract}
This article highlights an emerging research agenda for the study of foreign aid through a World Society Theory lens. First, it briefly summarizes the social scientific literature on aid and sociologists' earlier contributions to this research. Next, it reviews the contours of world society research and the place of aid within this body of literature. Finally, it outlines three emergent threads of research on foreign aid that comprise a new research agenda for the sociology of foreign aid and its role in world society globalization.
\end{abstract}

\section{Keywords}

Foreign Aid; World Society; Globalization; Development; Organizations

\footnotetext{
${ }^{1}$ I want to thank Andrew Dawson, Lars Engberg-Pedersen, and Wesley Longhofer for feedback on earlier drafts of this article. Contact: Liam Swiss, Department of Sociology, Memorial University, St. John's, NL, Canada lswiss@mun.ca or @liamswiss
} 


\section{A Sociology of Foreign Aid and the World Society}

Clearly, our island society would quickly come under the scrutiny of all these international organizations. [...] The organizations themselves would also directly "aid" our island society in "developing." They would provide models for data, organization, and policy; training programs to help the island's elites learn the correct high forms of principle, policy, and structuration; consultants to provide hands-on assistance; and evaluation schemes to analyze the results. (Meyer et al. 1997a)

\section{DEVELOPMENT AID AND THE ISLAND SOCIETY?}

What would happen if a previously undiscovered island society was suddenly revealed to and integrated within the global community? This hypothetical addressed in the quote above helped frame John Meyer and his co-authors' foundational 1997 article "World Society and the Nation State.” The short answer? The island society would join the international community and start to develop and exhibit all the institutional forms that comprise a legitimate state. This insight has been undeniably influential in the sociological study of globalization and transnational norms ever since and been cited by more than 3500 times since its publication.

The World Society perspective has spawned many significant empirical and theoretical advances in the nearly 20 years since, not the least of which are new approaches to thinking about diffusion, international norms, and the role of international actors in the globalization process (Beckfield 2008, 2010; Boli and Thomas 1997; Boli and Thomas 1999; Drori, Meyer and Hwang 2006; Drori et al. 2003; Lechner and Boli 2005; Meyer 2007; Meyer et al. 1997b). Yet, these contributions remain mostly silent on one aspect of World Society deserving of sociologists’ attention: the role played by foreign aid in World Society. To this end, this article examines how foreign aid/development assistance is implicated in funding international organizations and states in their diffusion and adoption of the world cultural norms and scripts, and surveys recent 
scholarship to highlight the emerging research agenda for a neo-institutional sociology of foreign aid.

First, I provide a brief overview of the state of foreign aid research broadly. Next, I discuss what World Society Theory offers a sociology of foreign aid. Finally, I outline several emerging threads that comprise a research agenda for a sociology of foreign aid in the World Society.

\section{MOTIVES, IMPACT, AND POLICY: CURRENT FOREIGN AID RESEARCH}

For the sake of parsimony, I will distill the vast interdisciplinary research literature on aid into three categories: (1) research on the motives behind aid; (2) research on the effects/impact and allocation of aid; and (3) research on aid policy and practices. Each category has a long history in the social sciences, but has received relatively limited attention from sociologists. Indeed, aid research has primarily been the purview of economists, political scientists, and anthropologists for much of the past 50 years. As a result, insufficient attention has been paid, I argue, to the role aid plays in globalization of norms and institutions - something that sociologists are well-placed to change.

\section{Motives behind aid}

Debates about aid motives have preoccupied the study of foreign aid since its outset. Some argue that official aid is a projection of donor foreign policy interests into the social and economic domain (Alesina and Dollar 2000; Dreher, Nunnenkamp and Thiele 2011; Lancaster 2007; Morgenthau 1962). Others argue aid is motivated by an altruism and humanitarian internationalism - wanting to help those in developing societies combat poverty and inequality (Lumsdaine 1993; Opeskin 1996). While still others argue that aid is little but the manifestation of a discourse of domination and power over the South by the North (Crush 1995; Escobar 1995; 
Ferguson 1994; Marchand and Parpart 1995). None of these schools of thought adequately address the role of foreign aid in the processes of globalization. Whether a tool of donor interest, an altruistic form of solidarity, or a power-laden discourse, foreign aid remains intrinsically linked to globalization, and requires application of novel theoretical approaches to account for this link.

\section{Impact and allocation of aid}

Research on the impact of aid focuses on the question of whether aid has worked. Has aid promoted development? Has it eliminated poverty? Has it promoted democracy? Has it contributed to peace and stability? Invariably one can find research to support both affirmative and negative responses to all of these questions (Altincekic and Bearce 2014; Gibson, Hoffman and Jablonski 2015; Kersting and Kilby 2014; Knack 2004; Moyo 2009; Robinson 1996; Stiglitz and Charlton 2006; Uvin 1998; William Martin and Prasad 2014; Woods 2005, 2008; Zürcher 2012). Others look at how aid is allocated at the country, district, and local community level, investigating how aid's interaction with politics, economy, and society determines its allocation (Brass 2012; Briggs 2014; Lee and Lim 2014; Winters and Martinez 2015). Regardless of the corpus of research addressing aid's developmental impact and allocation, very little has been written that examines how these factors play into globalization of norms and organizational forms.

\section{Aid policy and practice}

A third preoccupation of the aid literature - particularly since the turn of the $21^{\text {st }}$ century - has been the examination of and desire to improve aid policy. Often labeled under the category of aid effectiveness, researchers frequently provide advice to governments, NGOs, and international actors about how best to structure aid programs for maximum efficiency and results (Acharya, de 
Lima and Moore 2006; Addison, Mavrotas and McGillivray 2005; Aldasoro, Nunnenkamp and Thiele 2010; Booth 2012; Brown 2012; Stokke and Hoebink 2005). Likewise, researchers have focused on how policy innovations have been implemented in the aid sector (Brown and Swiss 2013; Easterly 2007; Easterly and Williamson 2011; Engberg-Pedersen 2014; Knack, Rogers and Eubank 2011). The aid policy literature has largely overlooked the link between aid policy and the spread of global norms and institutions. Though some studies link the spread of aid policies among donors to the influence of World Society norms and organizations (Chabbott 1999; Swiss 2011, 2012), more work is required to help explain how different aid policies contribute to globalization and norm proliferation.

\section{A SOCIOLOGY OF FOREIGN AID}

What have sociologists contributed to the study of aid? Most commonly, the sociology of aid has been framed through the lens of: workers in the aid industry (Cook 2012; Fast 2010, 2014; Jackson 2005); aid NGOs (Chabbott 1999; Jalali 2013; Schnable 2015a; Watkins, Swidler and Hannan 2012); donor agencies and multilateral banks (Babb 2007, 2009; Jones and Swiss 2014; Swiss 2011, 2012, 2014); aid's developmental impact (Shandra, Shandra and London 2011; Shandra, Shircliff and London 2011); or issues of public support (Paxton and Knack 2012; Schnable 2015b).

This article argues that running through this extant sociology of aid is a potentially pivotal research agenda on aid and the World Society through which sociologists can make a unique contribution to the study of foreign aid. Indeed, many of those that have previously addressed aid from this perspective allude to such an approach, but have not previously articulated a 
coherent neo-institutional approach to studying aid (Babb 2001; Barrett and Tsui 1999; Chabbott 1999; Jackson 2005; Nielsen and Simmons 2015).

Rather than retread past work on aid as all of the above manifestations of North-South relations, an emerging World Society approach to aid should instead investigate aid's role as a key transnational mechanism of globalization. In particular, such an approach should examine aid's role in spreading common norms, policies, and institutions among states of the Global South, and in linking developing countries to networks of global actors. Before mapping the nascent outlines of this World Society approach to aid, I first examine the roots of this framework in the ground laid by prior World Society research.

\section{World Society Theory}

The World Society Theory of globalization evolved as a distinct body of literature in political and global/transnational sociology over several decades. The core claim of this theory is that states act and appear alike because they adopt similar norms, policies, and organizational frames to regulate and legitimize everyday aspects of life in their society (Meyer et al. 1997a). These norms, policies, and institutions circulate globally among societies and rise from the work of experts and professionals within networks and alliances of actors such as international nongovernmental (INGOs) and inter-governmental organizations (IGOs) like the United Nations (UN), the Organization for Economic Cooperation and Development (OECD), the Red Cross, Amnesty International, or Greenpeace (Boli and Thomas 1997; Boli and Thomas 1999; Schofer et al. 2012). These actors shape and spread common policy models or scripts which states and other organizations adopt to gain legitimacy on the global stage and among their citizens.

Explaining of the diffusion of norms and institutions globally is a strength of this approach (Schofer et al. 2012). Indeed, World Society research has explained the striking similarities that 
we see among diverse societies in areas as divergent as education, corporate social responsibility, anti-corruption, planning, environmental protection, sexualities, human rights, gender equality, and even some aspects of the foreign aid sector (Berkovitch 1999; Clark and Hall 2011; Cole 2005, 2012; Cole and Ramirez 2013; Forbis 2013; Frank, Camp and Boutcher 2010; Frank, Hardinge and Wosick-Correa 2009; Hafner-Burton and Tsutsui 2005; Hwang 2006; Lim and Tsutsui 2012; Schofer and Hironaka 2005; Tsutsui and Wotipka 2004).

Understanding diffusion is critical to understanding globalization, however, not all World Society models and institutions penetrate states equally, with states in the developing world often marginalized from World Society networks and organizations or less able to implement norms or policies properly (Beckfield 2003; Clark 2010; Cole and Ramirez 2013; Swiss 2009). The gap between intent and implementation or policy and practice - often labeled loose coupling or decoupling - has become another central focus of World Society research in recent years. Analyzing membership in global networks of key World Society actors has been one means of trying to map out the contours of power and inequality in World Society to establish a more detailed account for why some states are more connected than others, or why others are better able to implement certain policies and practices (Beckfield 2008, 2010; Hughes et al. 2009; Paxton, Hughes and Reith 2015).

Research on World Society has evolved into a cohesive school of thought on how globalization of institutions and norms functions. Yet, given the connections of the aid sector to these same global networks, and the clear role aid plays in policy and institutional reforms, World Society research has infrequently touched on the role aid plays in this process (Chabbott 1999; Kühl 2015; Peterson 2014). 


\section{Emerging Threads: Aid and the World Society}

Recent evidence suggests this pattern is changing, with increased attention being paid to foreign aid by sociologists engaged in World Society research. In this context several threads that comprise a World Society approach to the sociology of aid are beginning to emerge. I will focus here on three: (1) aid's role in the diffusion of World Society norms and models; (2) aid actors as World Society actors; and (3) aid networks and their overlap with other World Society networks.

\section{Aid and Diffusion}

The treatment of aid in some World Society writing has been as a control or secondary independent variable in cross-national statistical examinations of World Society processes and actors. For instance, researchers have hypothesized roles for aid - bilateral and multilateral - in the diffusion of various institutions, including stock exchanges (Weber, Davis and Lounsbury 2009), legislation (Kim et al. 2013), women’s rights (Berkovitch and Bradley 1999), environmental policy (Frank, Longhofer and Schofer 2007), and central banking policy (Polillo and Guillén 2005) among others. Others have shown that aid is responsive to country adoption of specific types of population policies (Barrett and Tsui 1999). Not least, Chabbott (1999) argues that the work of development INGOs has played a critical role in weaving a 'developmental obligation' into the fabric of World Society. These studies all suggest the need for a more serious understanding of how aid helps facilitate the World Society diffusion of norms and underpins institutional isomorphism among countries. Through assisting in the diffusion and implementation of world cultural models, aid may be a key mechanisms through which the decoupling gaps often linked to weaker states might be narrowed. 
Aid's role in the spread of 'beneficial' developmental norms and institutions is not uniform, as other research has highlighted its potentially disruptive effects. For example, specific types of aid have been seen to negatively impact the achievement of women's rights (Yoo 2011), child welfare (Bradshaw et al. 1993), and environmental protection (Shandra, Shircliff and London 2011). The countervailing effects of certain forms of aid on the spread of World Society institutional forms is thus an integral piece of understanding how aid is implicated in globalization and institutional isomorphism. World society researchers often focus on the spread of 'positive' or 'desirable' norms and practices; but can the same global networks of aid donors and actors also help spread less-desirable outcomes? Disaggregating aid's effects according to type of actor involved and aid offered may help us better understand the sometimes unintended consequences and downsides of development and globalization.

\section{Aid and Organizations}

Part of understanding the role aid plays in global norm diffusion is to view aid relationally and not simply as a transfer of financial resources. International and domestic organizations both send and deliver aid in all its forms. In this sense, aid embodies transnational relations among many of the 'rational actors' of World Society - facilitating the movement of ideas, expertise, and people between organizations, governments, and societies (Chabbott 1999; Peterson 2014).

Aid as a global institution both shapes and is shaped by these relationships. Like has been shown in other policy contexts (Alasuutari 2011, 2015; Alasuutari and Rasimus 2009), international organizations like the UN and the OECD act as reference points and brokers who facilitate the spread of aid policies and priorities among donor agencies (Eyben 2013; Swiss 2011, 2012). This is not to say that donors are homogenous, as considerable heterogeneity exists between 
donor countries, and indeed within specific donors over time, in terms of which countries and development priorities they fund.

Still, official aid promotes ties between countries and organizations in World Society (Peterson 2014). Aid NGOs adopt and implement new agendas based on prevailing trends in development discourse (Chabbott 1999) and will also chase donor funding to sustain their organizations by shifting their focus to new development vogues or new 'donor darling' recipient countries (Cooley and Ron 2002). Aid organizations excel at creating and growing new organizations in aid recipient countries, often times employing these new organizations as a means to the end of 'development' (Kühl 2015). It is not surprising, then, that aid is linked to the increased presence of domestic civil society and voluntary associations (Schofer and Longhofer 2011). Such processes lead to new connections between organizations, individuals, and even countries. In this sense, seeing aid as a social relationship between organizations or between countries is a logical complement to the inherently relational nature of World Society (Peterson 2014).

\section{Aid Networks}

Networks of INGOs, IGOs, and other organizations often rely on aid as a relational mechanism that both promotes ties and funds their work. Understanding how aid ties or their absence contribute to the embeddeness of countries in World Society is a clear corollary of such an approach. While some research has used such social network ties to examine the implementation of aid policies in practice (Brown and Swiss 2013; Swiss and Brown 2015), there has only been very limited sociological research on aid as a global network of country and organizational ties (Peterson 2011; Swiss 2014). Through examining the relational ties of countries to intergovernmental and INGO networks, we can gain a sense of how connected countries are to World Society and better understand the contours of power and inequality within it (Beckfield 
2008, 2010; Hughes et al. 2009; Paxton, Hughes and Reith 2015). Given the overlap of aid actors, IGOs, and INGOs, a clearer picture of how aid networks function and their relationship to other global networks of IGO and INGO actors is another potential contribution of a sociology of foreign aid informed by World Society institutionalism (Swiss and Longhofer, Forthcoming).

\section{RESEARCH AGENDA: FOREIGN AID IN THE WORLD SOCIETY}

These threads form the basis of an emerging sociological research agenda on aid in the World Society. This agenda will help sociologists illustrate the processes and mechanisms through which Meyer and colleagues' newly discovered island nation will be brought into World Society through aid and development. What norms, policies, international treaties, and practices would aid help institutionalize there? How would aid funds provide the resources through which this institutionalization occurred? What new INGOs and IGOs would aid force the island society join? Which INGOs and other development actors would flock to the island as a new donor darling? How would the island become linked into global networks of World Society and the global aid network itself? All of these questions are answerable within a research agenda that takes seriously the examination of foreign aid's role in World Society theory. By building on the existing interdisciplinary research literature on foreign aid and more closely examining foreign aid's place as a mechanism of globalization in World Society theory, sociologists stand to make a valuable contribution to the study of foreign aid and at the same time better explain an often overlooked transnational process through which World Society functions. 


\section{REFERENCES}

Acharya, Arnab, Ana Teresa Fuzzo de Lima, and Mick Moore. 2006. "Proliferation and fragmentation: Transactions costs and the value of aid." Journal of Development Studies 42(1):1-21.

Addison, Tony, George Mavrotas, and Mark McGillivray. 2005. "Development Assistance and Development Finance: Evidence and Global Policy Agendas." Journal of International Development 17:819-36.

Alasuutari, Pertti. 2011. "The governmentality of consultancy and competition: The influence of the OECD." Pp. 147-65 in Mapping out the research-policy matrix: Highlights from the First International Forum on the Social Science-Policy Nexus, edited by German Solinis and Nicolas Baya-Laffite.

—. 2015. "The Discursive Side of New Institutionalism." Cultural Sociology 9(2):162-84.

Alasuutari, Pertti, and Ari Rasimus. 2009. "Use of the OECD in justifying policy reforms: the case of Finland." Journal of Power 2(1):89-109.

Aldasoro, I., P. Nunnenkamp, and R. Thiele. 2010. "Less aid proliferation and more donor coordination? The wide gap between words and deeds." Journal of International Development 22(7):920-40.

Alesina, A., and D. Dollar. 2000. "Who Gives Foreign Aid to Whom and Why?" Journal of Economic Growth 5(1):33-63.

Altincekic, Ceren, and David H. Bearce. 2014. "Why there Should be No Political Foreign Aid Curse." World Development 64(0):18-32.

Babb, S.L. 2001. Managing Mexico: Economists from nationalism to neoliberalism. Princeton, NJ: Princeton Univ Press. 
—. 2007. "Embeddedness, Inflation, and International Regimes: The IMF in the Early Postwar Period." American Journal of Sociology 113(1):128-64.

—. 2009. Behind the development banks: Washington politics, world poverty, and the wealth of nations: University of Chicago Press.

Barrett, Deborah, and Amy Ong Tsui. 1999. "Policy as Symbolic Statement: International Response to National Population Policies." Social Forces 78(1):213-33.

Beckfield, Jason. 2003. "Inequality in the world polity: The structure of international organization." American Sociological Review 68(3):401-24.

—. 2008. "The dual world polity: fragmentation and integration in the network of intergovernmental organizations." Social Problems 55(3):419-42.

—. 2010. "The Social Structure of the World Polity." American Journal of Sociology 115(4):1018-68.

Berkovitch, Nitza. 1999. "The Emergence and Transformation of the International Women's Movement." Pp. 100-26 in Constructing world culture : international nongovernmental organizations since 1875, edited by John Boli and George M. Thomas. Stanford, CA: Stanford University Press.

Berkovitch, Nitza, and Karen Bradley. 1999. "The Globalization of Women's Status: Consensus/Dissensus in the World Polity." Sociological Perspectives 42(3):481-98.

Boli, J., and George M. Thomas. 1997. "World culture in the world polity: A century of international non-governmental organization." American Sociological Review 62(2):17190.

Boli, John, and George M. Thomas. 1999. Constructing world culture : international nongovernmental organizations since 1875. Stanford, CA: Stanford University Press. 
Booth, David. 2012. "Aid effectiveness: bringing country ownership (and politics) back in." Conflict, Security \& Development 12(5):537-58.

Bradshaw, York W., Rita Noonan, Laura Gash, and Claudia Buchmann Sershen. 1993. "Borrowing against the Future: Children and Third World Indebtedness." Social Forces 71(3):629-56.

Brass, Jennifer N. 2012. "Why Do NGOs Go Where They Go? Evidence from Kenya." World Development 40(2):387-401.

Briggs, Ryan C. 2014. "Aiding and Abetting: Project Aid and Ethnic Politics in Kenya." World Development 64(0):194-205.

Brown, Stephen (Ed.). 2012. Struggling for Effectiveness: CIDA and Canadian Foreign Aid. Montréal: McGill-Queen's University Press.

Brown, Stephen, and Liam Swiss. 2013. "The Hollow Ring of Donor Commitment: Country Concentration and the Decoupling of Aid Effectiveness Norms from Donor Practice." Development Policy Review 31(6):737-55.

Chabbott, Collette. 1999. "Development INGOs." Pp. 222-48 in Constructing world culture : international nongovernmental organizations since 1875, edited by John Boli and George M. Thomas. Stanford, CA: Stanford University Press.

Clark, Rob. 2010. "Technical and Institutional States Loose Coupling in the Human Rights Sector of the World Polity." Sociological Quarterly 51(1):65-95.

Clark, Rob, and Jason Hall. 2011. "Migration, International Telecommunications, and Human Rights." Sociological Forum 26:870-96.

Cole, Wade M. 2005. "Sovereignty relinquished? Explaining commitment to the international human rights covenants, 1966-1999." American Sociological Review 70(3):472-95. 
—. 2012. "Human Rights as Myth and Ceremony? Reevaluating the Effectiveness of Human Rights Treaties, 1981-2007." American Journal of Sociology 117(4):1131-71.

Cole, Wade M, and Francisco O Ramirez. 2013. "Conditional Decoupling Assessing the Impact of National Human Rights Institutions, 1981 to 2004." American Sociological Review.

Cook, Nancy. 2012. "Canadian development workers, transnational encounters and cultures of cosmopolitanism." International Sociology 27(1):3-20.

Cooley, A., and J. Ron. 2002. "The NGO scramble: Organizational insecurity and the political economy of transnational action." International Security 27(1):5-39.

Crush, J. S. 1995. Power of development. London New York: Routledge.

Dreher, Axel, Peter Nunnenkamp, and Rainer Thiele. 2011. "Are 'New’ Donors Different? Comparing the Allocation of Bilateral Aid Between nonDAC and DAC Donor Countries." World Development 39(11):1950-68.

Drori, G. S., J. W. Meyer, and H. Hwang. 2006. Globalization and Organization: World Society and Organizational Change. New York: Oxford University Press.

Drori, Gili S., John W. Meyer, Francisco O. Ramirez, and Evan Schofer. 2003. Science in the modern world polity : institutionalization and globalization. Stanford, Calif.: Stanford University Press.

Easterly, William. 2007. "Are aid agencies improving?" Economic Policy 22(52):633-78.

Easterly, William, and Claudia R. Williamson. 2011. "Rhetoric versus Reality: The Best and Worst of Aid Agency Practices." World Development 39(11):1930-49.

Engberg-Pedersen, Lars. 2014. "Bringing Aid Management Closer to Reality: The Experience of Danish Bilateral Development Cooperation." Development Policy Review 32(1):113-31. 
Escobar, Arturo. 1995. Encountering development : the making and unmaking of the Third World. Princeton, N.J.: Princeton University Press.

Eyben, Rosalind. 2013. "Struggles in Paris: The DAC and the purposes of development aid." European Journal of Development Research 25(1):78-91.

Fast, Larissa A. 2010. "Mind the gap: Documenting and explaining violence against aid workers." European Journal of International Relations 16(3):365-89.

—. 2014. Aid in Danger. Philadelphia: University of Pennsylvania Press.

Ferguson, James. 1994. The anti-politics machine : "development," depoliticization, and bureaucratic power in Lesotho. Minneapolis: University of Minnesota Press.

Forbis, Jeremy S. 2013. "Organized Civil Society: A Cross-national Evaluation of NonGovernmental Organization Density on Governmental Corruption." Sociological Focus 46(3):159-77.

Frank, David John, Bayliss J Camp, and Steven A Boutcher. 2010. "Worldwide trends in the criminal regulation of sex, 1945 to 2005." American Sociological Review 75(6):867-93.

Frank, David John, T. Hardinge, and K. Wosick-Correa. 2009. "The global dimensions of rapelaw reform: A cross-national study of policy outcomes." American Sociological Review 74(2):272-90 .

Frank, David John, Wesley Longhofer, and Evan Schofer. 2007. "World Society, NGOs and Environmental Policy Reform in Asia." International Journal of Comparative Sociology 48(4):275-95.

Gibson, Clark C., Barak D. Hoffman, and Ryan S. Jablonski. 2015. "Did Aid Promote Democracy in Africa? The Role of Technical Assistance in Africa’s Transitions." World Development 68(0):323-35. 
Hafner-Burton, Emilie, and Kiyoteru Tsutsui. 2005. "Human Rights in a Globalizing World: The Paradox of Empty Promises." American Journal of Sociology 110(5):1373-411.

Hughes, M.M., L. Peterson, J.A. Harrison, and P. Paxton. 2009. "Power and Relation in the World Polity: The INGO Network Country Score, 1978-1998." Social Forces 87(4):1711-42.

Hwang, H. 2006. "Planning Development: Globalization and the Shifting Locus of Planning." Pp. 69-89 in Globalization and Organization: World Society and Organizational Change, edited by G. S. Drori, J. W. Meyer, and H. Hwang. New York: Oxford University Press.

Jackson, J.T. 2005. The globalizers: development workers in action. Baltimore, MD: Johns Hopkins University Press.

Jalali, Rita. 2013. "Financing Empowerment? How Foreign Aid to Southern Ngos and Social Movements Undermines Grass-Roots Mobilization." Sociology Compass 7(1):55-73.

Jones, Robert C., and Liam Swiss. 2014. "Gendered Leadership: The Effects of Female Development Agency Leaders on Foreign Aid Spending." Sociological Forum 29(3):57186.

Kersting, Erasmus, and Christopher Kilby. 2014. "Aid and democracy redux." European Economic Review 67(0):125-43.

Kim, Minzee, Wesley Longhofer, Elizabeth Heger Boyle, and Hollie Nyseth Brehm. 2013. "When Do Laws Matter? National Minimum-Age-of-Marriage Laws, Child Rights, and Adolescent Fertility, 1989-2007." Law \& Society Review 47(3):589-619.

Knack, Stephen. 2004. "Does Foreign Aid Promote Democracy?" International Studies Quarterly 48(1):251-66. 
Knack, Stephen, F. Halsey Rogers, and Nicholas Eubank. 2011. "Aid Quality and Donor Rankings." World Development 39(11):1907-17.

Kühl, Stefan. 2015. "The Diffusion of Organizations: The Role of Foreign Aid." Pp. 258-78 in From Globalization to World Society. Neo-Institutional and Systems-Theoretical Perspectives, edited by Holzer Boris, Kastner Fatima, and Werron Tobias. London: Routledge.

Lancaster, Carol. 2007. Foreign aid : diplomacy, development, domestic politics. Chicago: University of Chicago Press.

Lechner, Frank J., and John Boli. 2005. World Culture: Origins and Consequences. London: Blackwell.

Lee, Suejin A., and Jae-Young Lim. 2014. "Does International Health Aid Follow Recipients' Needs? Extensive and Intensive Margins of Health Aid Allocation." World Development 64(0):104-20.

Lim, Alwyn, and Kiyoteru Tsutsui. 2012. "Globalization and Commitment in Corporate Social Responsibility Cross-National Analyses of Institutional and Political-Economy Effects." American Sociological Review 77(1):69-98.

Lumsdaine, David Halloran. 1993. Moral vision in international politics : the foreign aid regime, 1949-1989. Princeton, N.J.: Princeton University Press.

Marchand, Marianne H., and Jane L. Parpart. 1995. Feminism/postmodernism/development. London New York: Routledge.

Meyer, J.W., J. Boli, George M. Thomas, and Francisco O. Ramirez. 1997a. "World society and the nation-state." The American Journal of Sociology 103(1):144-81. 
Meyer, John W. 2007. "Globalization: Theory and Trends." International Journal of Comparative Sociology 48(4):261-73.

Meyer, John W., David John Frank, Ann Hironaka, Evan Schofer, and Nancy Brandon Tuma. 1997b. "The structuring of a world environmental regime, 1870-1990." International Organization 51(4):623.

Morgenthau, Hans. 1962. "A Political Theory of Foreign Aid." The American Political Science Review 56(2):301-09.

Moyo, D. 2009. Dead Aid: Why Aid Is Not Working and How There Is a Better Way for Africa. New York: Farrar Straus \& Giroux.

Nielsen, Richard A., and Beth A. Simmons. 2015. "Rewards for Ratification: Payoffs for Participating in the International Human Rights Regime?" International Studies Quarterly 59(2):197-208.

Opeskin, B.R. 1996. "The Moral Foundations of Foreign Aid." World Development 24(1):21-44.

Paxton, Pamela, Melanie M Hughes, and Nicholas Reith. 2015. "Extending the INGO Network Country Score, 1950-2008." Sociological Science 2:287-307.

Paxton, Pamela, and Stephen Knack. 2012. "Individual and country-level factors affecting support for foreign aid." International Political Science Review 33(2):171-92.

Peterson, L.P. 2011. "Foreign Aid, INGOs and Development: A Cross-National and Longitudinal Examination of the Global Development System." Pp. 226 in Department of Sociology. Columbus, OH: The Ohio State University.

Peterson, Lindsey. 2014. "A Gift You Can’t Refuse? Foreign Aid, INGOs and Development in the World Polity." Studies in Emergent Order 7:81-102. 
Polillo, Simone, and Mauro F. Guillén. 2005. "Globalization Pressures and the State: The Worldwide Spread of Central Bank Independence." American Journal of Sociology 110(6):1764-802.

Robinson, William I. 1996. "Globalization, the world system, and "democracy promotion" in U.S. foreign policy." Theory \& Society 25(5):615-65.

Schnable, Allison. 2015a. New American Relief and Development Organizations: Voluntarizing Global Aid.

—. 2015b. "Religion and Giving for International Aid: Evidence from a Survey of U.S. Church Members." Sociology of Religion 76(1):72-94.

Schofer, Evan, and Ann Hironaka. 2005. "The Effects of World Society on Environmental Protection Outcomes." Social Forces 84(1):25-47.

Schofer, Evan, Ann Hironaka, David John Frank, and Wesley Longhofer. 2012. "Sociological Institutionalism and World Society." Pp. 57-68 in The Wiley-Blackwell Companion to Political Sociology, edited by E. Amenta, K Nash, A., and A. Scott. Malden, MA: WileyBlackwell.

Schofer, Evan, and Wesley Longhofer. 2011. "The Structural Sources of Association." American Journal of Sociology 117(2):539-85.

Shandra, Carrie L., John M. Shandra, and Bruce London. 2011. "World Bank Structural Adjustment, Water, and Sanitation: A Cross-National Analysis of Child Mortality in SubSaharan Africa." Organization \& Environment 24(2):107-29.

Shandra, John M., Eric Shircliff, and Bruce London. 2011. "The International Monetary Fund, World Bank, and structural adjustment: A cross-national analysis of forest loss." Social Science Research 40(1):210-25. 
Stiglitz, Joseph E, and Andrew Charlton. 2006. "Aid for trade." International Journal of Development Issues 5(2):1-41.

Stokke, Olav, and Paul Hoebink. 2005. Perspectives on European development co-operation : policy and performance of individual donor countries and the EU. London: Routledge.

Swiss, Liam. 2009. "Decoupling Values from Action: An Event-History Analysis of the Election of Women to Parliament in the Developing World, 1945-90." International Journal of Comparative Sociology 50(1):69-95.

—. 2011. "Security Sector Reform and Development Assistance: Explaining the Diffusion of Policy Priorities Among Donor Agencies." Qualitative Sociology 34(2):371-93.

—. 2012. "The Adoption of Women and Gender as Development Assistance Priorities: An Event History Analysis of World Polity Effects." International Sociology 27(1):96-119.

—. 2014. "Mimicry and Motives: Canadian Aid Allocation in Longitudinal Perspective." Pp. 101-24 in Rethinking Canadian Aid, edited by Stephen Brown, Molly den Heyer, and David. R. Black. Ottawa: University of Ottawa Press.

Swiss, Liam, and Stephen Brown. 2015. "The aid orphan myth." Third World Quarterly 36(2):240-56.

Swiss, Liam, and Wesley Longhofter. Forthcoming. “Membership has its privileges: Shared international organizational affiliation and foreign aid flows, 1978-2010” Social Forces.

Tsutsui, Kiyoteru, and Christine Min Wotipka. 2004. "Global civil society and the international human rights movement: Citizen participation in human rights international nongovernmental organizations." Social Forces 83(2):587-620.

Uvin, P. 1998. Aiding Violence: The Development Enterprise in Rwanda. London: Kumarian Press. 
Watkins, Susan Cotts, Ann Swidler, and Thomas Hannan. 2012. "Outsourcing Social Transformation: Development NGOs as Organizations." Annual Review of Sociology 38(1):285-315.

Weber, Klaus, Gerald F Davis, and Michael Lounsbury. 2009. "Policy as myth and ceremony? The global spread of stock exchanges, 1980-2005." Academy of Management Journal 52(6):1319-47.

William Martin, Isaac, and Monica Prasad. 2014. "Taxes and Fiscal Sociology." Annual Review of Sociology 40(1):331-45.

Winters, Matthew S., and Gina Martinez. 2015. "The Role of Governance in Determining Foreign Aid Flow Composition." World Development 66(0):516-31.

Woods, Ngaire. 2005. "The Shifting Politics of Foreign Aid." International Affairs 81(2):393409.

—. 2008. "Whose aid? Whose influence? China, emerging donors and the silent revolution in development assistance." International Affairs 84(6):1205-21.

Yoo, Eunhye. 2011. "International human rights regime, neoliberalism, and women’s social rights, 1984-2004." International Journal of Comparative Sociology 52(6):503-28.

Zürcher, Christoph. 2012. "Conflict, state fragility and aid effectiveness: insights from Afghanistan." Conflict, Security \& Development 12(5):461-80. 